\title{
sciendo
}

\section{The impact of COVID-19 on consumer behavior in retail banking. Evidence from Romania}

\author{
Claudia Gabriela BAICU \\ Institute for World Economy, Romanian Academy, Bucharest, Romania \\ Iuliana Petronela GÂRDAN \\ Spiru Haret University, Faculty of Economic Sciences, Bucharest, Romania \\ gardanpetronela@yahoo.com \\ Daniel Adrian GÂRDAN \\ Spiru Haret University, Faculty of Economic Sciences, Bucharest, Romania \\ Gheorghe EPURAN \\ Transylvania University of Brasov, Faculty of Economic Sciences and Business Administration, \\ Brasov, Romania
}

\begin{abstract}
The pandemic COVID-19 has severely affected the global economy. The strict lockdown measures have also changed the daily live, including consumer behavior in retail banking. In this context, the purpose of this paper is to investigate the impact of the COVID-19 crisis on consumer behavior in retail banking, with a special focus on the Romanian banking sector. To achieve our goal, we performed a survey among the Romanian consumers in retail banking, using as research method the field survey based on questionnaire. The final sample comprised 738 valid responses from the metropolitan area retail banking consumers. The research brings a fresh insight on retail banking services consumption during the pandemic and validates a conceptual model regarding the internet and mobile banking services acceptance. The research' results highlighted, among others, that the variable concerning the perception of the COVID-19 pandemic effect on consumers' lifestyle has a direct and positive influence on the variable regarding the attitude toward internet and mobile banking services, mediated by other variables like safety of internet and mobile banking use and trust in banks. Several social and managerial implications are also discussed, because it is possible that the tendency to use internet and mobile banking services will prevail even after the post pandemic stage, as new consumption behavior models are developing. Banks in Romania should increase their initiatives to offer financial education courses and online tutorials to familiarize customers with the use of digital channels. Banks should also improve communication with clients and design new products and services to increase the attractiveness of saving process. They should demonstrate flexibility in negotiating lending and refinancing conditions as well.
\end{abstract}

Keywords: retail banking, the COVID-19 pandemic, internet and mobile banking, consumer behavior.

Please cite the article as follows: Baicu, C.G., Gârdan, I. P., Gârdan, D.A., Epuran, G., (2020), "The impact of COVID-19 on consumer behavior in retail banking. Evidence from Romania", Management \& Marketing. Challenges for the Knowledge Society, Vol. 15, No. Special Issue, pp. 534-556, DOI: 10.2478/mmcks-2020-0031. 


\section{Introduction}

The COVID-19 pandemic has severely affected the global economy and daily life, as well as the banking sector that has to meet the expectations and challenges households and business are facing following the strict lockdown initiatives implemented to diminishing the coronavirus spread. To help clients in lack of liquidity, many governments have offered public guarantees on banks loans and approved moratorium on credits. The COVID-19 effects on the banking sector include the intensifying use of digital channels and digital payments; the change of consumer behavior; relaxation of several regulatory and supervisory provisions, but also new challenges regarding operational resilience and increase of non-performing loans.

The impact of COVID-19 on business and consumer behavior change is a topic of great importance for companies and financial industry around the world not only to take actions on short-term, but, even more important, to reconsider their strategy on medium and long term.

In this context, our key hypothesis is that the COVID-19 crisis has also changed the consumer behavior in retail banking in Romania. More precisely, the retail consumers have been obliged to use more digital payments to cash detriment and digital channels to the classic channels detriment, to fully adapt and embrace the new channels and technologies. Thus, the results of our research validate the Technology Acceptance Model (TAM) into the field of internet and mobile banking services. We also assume that the high uncertainties and concerns raised by the COVID-19 crisis will cause the decrease of the Romanian retail clients' appetite towards credits.

Against this backdrop, we organized the remaining part of the paper as follows:

- the first section is devoted to the review of the pandemic literature related to the impact of coronavirus on the banking sector, emphasizing the effects on consumer behavior in retail banking; banks' strategies in response to COVID-19; measures adopted to mitigate the coronavirus impact in terms of liquidity, lending capacity and regulatory framework;

- the second section analyses the changes in consumer behavior in retail banking in Romania, testing a model that demonstrates the validity of Technology acceptance model variables within the context created by the COVID-19 pandemic;

- conclusions and future directions of research are presented in the final part of the paper, several social and managerial implications being also emphasized.

\section{Literature review}

Trends in consumer behavior in retail banking and their impact on banks strategies

Against the backdrop of the lockdown and social distancing imposed to diminish the widespread of the virus, a direct consequence of COVID-19 is the increase use of online services. The shift towards online shopping in China is underscored by Craven et al. (2020), moreover, the authors consider that "Customers' changing preferences are not likely to go back to preoutbreak norms". Following this likely change in the customer buying preference, the business model of banks will be strongly influenced, the channels of distribution being one of the most impacted banking dimension (Pop, 2020).

Hoe (2020) reports some trends in consumer behavior determined by the measures to limit physical contact and cash use under the pandemic crisis: there was an increase in the registration of banking account with digital banks in South-East Asia; similar, the 
opening of online banking accounts of small and medium-size enterprises in Malaysia intensified; the limit for the contactless payment was increased in the UK.

The emergent literature on the COVID-19 impact on banks includes the Buehler et al. (2020) study. Regarding the retail consumers, the authors underline that banks should encourage the use of remote services by launching "positive and safety-oriented messaging" to reduce the reliance on physical locations. From this perspective, banks should take into consideration all consumer segments, among which the older part of population that are particularly exposed to COVID-19 and more reticent to embrace digital services. In the context of drop in branch visits, banks should simplify their online interfaces and provide clients with educational materials on how to use the nonbranch channels (eMarketer, 2020). For example, webinars and customized teach-ins are among the measures adopted by the Singapore's DBS bank following the corona virus outbreak to train their customers to use digital channels (Finextra, 2020).

By analyzing the effect of the COVID-19 pandemic on the use of cash and payments, the work of Auer, Cornelli and Frost (2020) underlines that the shift toward digital payments might have a negative impact on older and unbanked consumer, which suggests that cash have to be defended. The same work reviews the behavior towards cash and the measures taken by several governments and central banks: some countries, including India and Indonesia, have encouraged the use of cashless payments; several central banks, such as the Fed, central banks in China, South Korea, Hungary have sterilized and quarantined banknotes; at the same time, other central banks (for example, the Bundesbank, the South African Reserve Bank) have promoted trust in cash, communicating that the risk of coronavirus transmission through banknotes is low.

According to the World Bank analysis of the COVID-19 financial sector support measures, low-income countries have taken actions to promote the use of digital channels in the payment sector, such as waiving charges, fees and simplifying digital identification procedures (Mora, 2020). There is a change in the attitude of consumers in using internet opportunities (Celic et al., 2018).

A major issue for bankers, consultants, strategists, academics and other stakeholders is to conceive successful strategies for banks in order to better adapt to the new environment marked by highly uncertainty. Nowadays organizations are facing a tremendous pace of change within the marketing environment that calls for flexible approaches and marketing strategies (Pop, 2020). To this respect, among their proposals, Vessey, Ott and Dimidschstein (2020) point that financial institutions should develop those digital capabilities that maintain a "human touch", allowing them to better interact and support their clients (for example, live chat or video calling). The importance of chat channels for banks customers' during social distancing imposed by Covid-19 is highlighted by McCarty (2020) as well.

Melamedov (2020) underlines that adoption of digital solutions will have impact on long term after the coronavirus pandemic and the traditional banks are invited to learn from the experience of digital financial institutions "neobanks" and fintechs. The exploration of partnerships with fintechs could be a way for banks to introduce new products (World Economic Forum, 2020).

Mergers within financial industry (bank mergers), but also outside financial services industry, will likely be among the post-COVID strategy of retail banks; at the same time, 
banks have to adapt their business models to the social changes related to the COVID-19 crisis (PwC, 2020).

\section{Measures to mitigate the negative effects of the COVID-19 crisis}

In order to cope with the negative impact of COVID-19 on companies and households, many governments around the globe have taken measures to increase their liquidity. Among these temporary measures, very important are public guarantees provided on loans granted by banks and payment moratoriums. As the Basel Committee on Banking Supervision recommends, the regulators should recognize this risk-reducing effects in the bank capital treatment of both loans subject to government guarantees and loans subject to payment moratoriums (BCBS, 2020).

The measures to mitigate the COVID-19 crisis in many European countries include moratorium on credits. For example, the Spanish Government has approved a moratorium on mortgage payments; in order to benefit from the moratorium, debtors have to meet certain conditions. Banks in France have allowed companies to defer credit repayments for up to 6 months. Italy has established a moratorium on loans to micro, small and mediumsized enterprises (Bichi, 2020).

In this context, the COVID-19 pandemic is likely to affect the bank ratings. Nevertheless, S\&P Global Ratings (2020) expect that, this year, the bank rating downgrades will be limited due to the public authorities support and strong capital and liquidity position of banks before the pandemic crisis.

From the banking regulation perspective, the COVID-19 crisis has determined regulatory authorities around the world to release countercyclical capital buffers in order to support lending to business and households. In March 2020, the British authorities have reduced the countercyclical capital buffer rate to $0 \%$ of banks' exposures to UK borrowers. Following this measures, the lending capacity of banks has increased up to $£ 190$ billion (Bank of England, 2020). However, as Drehmann et al. (2020) underline, the release of available buffers should not undermine the resilience of banks and the confidence in financial system. Therefore, policymakers are called to find a balance between preserving banks' lending capacity and banking sector resilience (Lewrick et al., 2020).

The work of Coelho and Prenio (2020) addresses the operational resilience of banks in a pandemic, by providing several examples of business continuity guidance. The authors underline that, according to the supervisory guidance issued in the Covid-19 context, financial institutions should incorporate pandemic scenarios in testing their operational resilience. Operational resilience of banks is also considered by Lewis (2020) that provides insight on some emerging threats banks have to face in the corona virus environment, among which: the potential fraudulent claims of applicants to access support schemes; cyber-attacks; increasing risks associated with data security; the challenges related to anti money laundering activities both from remote locations and on site with social distancing measure.

\section{Methodology of research}

\section{The research Hypothesis and the proposed conceptual model}

Starting from different insights on literature review regarding various variables that can help us to define consumer behavior in terms of internet and mobile banking services 
attitudes and consumption we developed a proposed theoretical model based on twelve hypothesis regarding the relationship between variables.

In order to properly assess the potential effect that the COVID-19 pandemic might have on the banking consumers' behavior, from the point of view of mobile/internet banking services degree of acceptance and usage, we began our discussion from the bottom of the nowadays-technological evolution. In many fields, technology has been used as a solution for all the problems, companies investing in research in order to maintain their competitive advantages (Bratianu et al., 2020a; Bratianu et al., 2020b; Gheorghiu et al., 2017; Crăciun et al., 2015). Companies along individuals are more and more oriented toward digital technologies nowadays (Dincă et al., 2019). Globalization has led to an increasing competitiveness in many business sectors and more sensitive data are transferred through different online channels (Vargas, 2019). Using more digital technology for banking services predisposes people to use digital channels of communication for other products or services and for social relationship too (Dima et al., 2018).

The first main concepts that can embrace essential changes in terms of consumer behavior from a technological point of view refer to the Theory of Reasoned Action (TRA), the Theory of Planned Behaviour (TPB) and the Technology Acceptance Model (TAM). Fishbein and Ajzen propose The Theory of Reasoned Action in the first place in 1975, considering that intention of an individual toward a certain behavior will definitively influence the behavior (Wu et al., 2014). The attitude of a person correlated with subjective norms is also influence the behavior to a great extent. The model also puts emphasis on individuals' cognition, affect and conation dimensions (Wu et al., 2014).

The Theory of Planned Behaviour (TPB) was developed later in 1985 by Ajzen, and it was an "upgrade" of the first theory meaning that perceived behavior control has been added, a concept referring to the fact that individuals can perceive their type and amount of resources disposable for a certain behavior (Zolait, 2014). Scholars determine the existence of some factors dealing with behavioral control like self-efficacy and different resources in terms of technology. It is for the first time that came to the open the idea that the type of innovation is actually important for the perceived behavior control (Zolait, 2014).

The Technology Acceptance Model (TAM) was proposed in 1989 and goes further with the TRA and TPB basics, putting emphasis on perceived usefulness and perceived ease of use related with an innovation (Waite and Harrison, 2015). Other approaches specific for the technology acceptance related to consumer behavior are the Diffusion of Innovation (DOI) Theory and the Extended Technology Acceptance Model - known as TAM 2. The DOI theory put emphasis on relative advantage of innovation, trialability and observability, while the TAM 2 introduces different antecedents and moderators that influence perceived usefulness and ease of use (Venkatesh and Davis, 2000).

Taking into account these concepts, we can ascertain several recent researches that put emphasis on their application. In a research made on 372 internet-banking users from Australia, results indicated that technology factors, channel factors and value-for-money factors partially influence consumers' post-adoption behaviour towards Internet banking (Adapa and Roy, 2017). In addition, perceived self-efficacy, perceived trust and perceived personalization exhibited a significant importance for the consumers' decision to continue the use of internet banking services. Same authors have also found out that social factors were important in relation with the pre-adoption and adoption behavior of internet banking but not with the continued use of it. 
Another research revealed that perceived usefulness and perceived ease of use are factors that influence the adoption of mobile technology regarding banking services along with the trust in banks (Zhang et al., 2018). Trust represents an important construct that can affect the consumer behavior within different contexts and different type of services. The content regarding the trust concept is developed from different perspectives, including social psychology, economics, philosophy and, of course, marketing research. It has been considered either a mental attitude, either a behavior based on intentional act of trusting. Trust will be definable differently according to the specific context of consumption or specific situation (Cătoiu et al., 2012). Within the bank services context, the relationship between banks and consumers is often a contractual one. This is why it seems appropriate to speak about different types or levels of trust, like contractual trust, competence trust and goodwill trust (Anneli Järvinen, 2014; Sako, 1992). In the banking services field trust will be dependent on the results of consumer experiences and consumer specific variables such as demographic ones. Different cultural traits and lifestyle related elements will influence the real capacity of consumers to exert trust upon banking services (Hadad and Brătianu, 2019).

Even if mobile marketing techniques have developed constantly over the last years, consumers are still sensible to some essential issues like security, trust, personalization, ease of use and different cultural traits that can determine different behaviors regarding mobile technology acceptance in various services consumption contexts, including banking services (Gârdan et al., 2011; Pelau et al., 2019).

In present context, one variable that can be taken into consideration is the perception of banking customers on the COVID-19 pandemic. In order to define it, we used the lifestyle concept as it can be considered a complex enough construct to define the perception of customers into a given consumption context (Van Acker, 2016). Within the context of the pandemic, the people lifestyle has changed essentially, especially during the isolation period imposed by authorities. The access to different services, including banking ones, has been limited and online solutions emerged as the all in one solution. hypotheses.

Taking account of the previous assertions, we proposed several research

H1. There is a direct and positive influence of perception of the COVID 19 pandemic effect on perceived utility of internet and mobile banking.

H.2. there is a direct and positive influence of perceived utility of internet and mobile banking on attitude towards internet and mobile banking.

H.3. there is a direct and positive influence of the perception of the COVID-19 pandemic effect on attitude towards internet and mobile banking.

H.4. There is a direct and positive influence of perception of the COVID-19 pandemic effect on ease of use of internet and mobile banking.

H.5. there is a direct and positive influence of ease of use of internet and mobile banking on attitude towards internet and mobile banking.

H.6. There is a direct and positive influence of perception of COVID-19 pandemic effect on trust in banks.

H.7. there is a direct and positive influence of perception of the COVID-19 pandemic effect on safety of internet and mobile banking use.

H.8. There is a direct and positive influence of safety of internet and mobile banking use perception on trust in banks. 
H.9. There is a direct and positive influence of trust in banks on attitude towards internet and mobile banking.

H.10. There is a direct and positive influence of safety of internet and mobile banking use on attitude towards internet and mobile banking.

H.11. There is a direct and positive influence of attitude towards internet and mobile banking on use of internet and mobile banking.

H.12. There is a direct and negative influence of attitude towards internet and mobile banking on perception of banks communication regarding online transactions risk exposure related to mobile and internet banking services use.

Starting from the above considerations, we proposed a theoretical model comprising the relationship between relevant variables that is illustrated in the figure 1 .

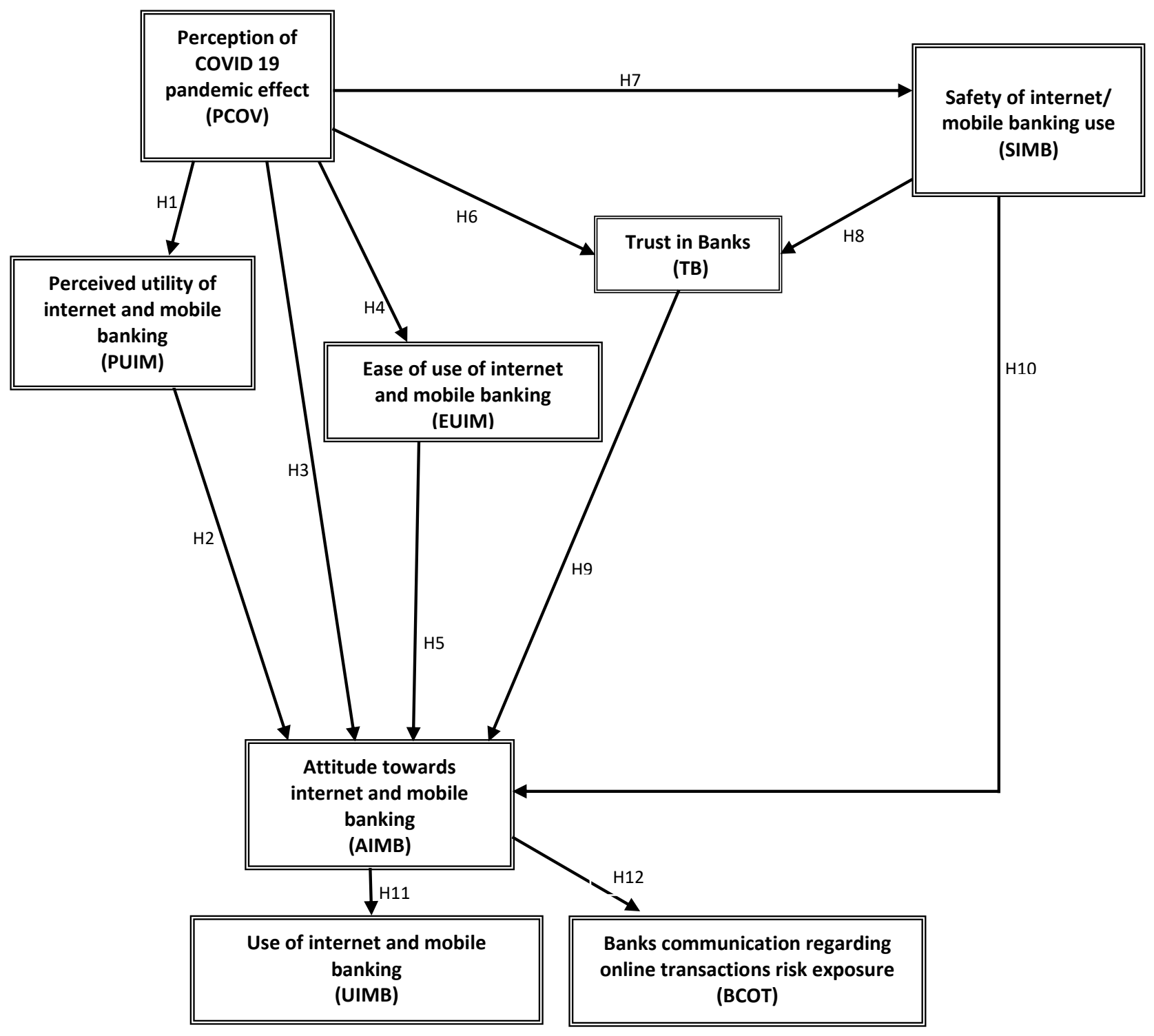

Figure1. The proposed conceptual model 


\section{Data description}

Starting from different insights on literature review regarding various variables that can help us to define consumer behavior in terms of internet and mobile banking services attitudes and consumption we proposed a theoretical model based on twelve hypotheses regarding the relationship between variables.

In order to validate and test the proposed conceptual model we developed a quantitative type research under the form of a field survey based on questionnaire. The questionnaire was accordingly developed and tested in order to eliminate possible content and form errors. We distributed the questionnaires using an online platform to random retail banking services customers from the urban metropolitan area. The answers were recorded during May 2020 and the final sample comprises 738 valid responses and presents the structure illustrated in the table 1 .

The selected sample is a convenience sample that allows the data weighting in order to have more representativeness of the statistical population with regard to certain characteristics (Malhotra, 2019; Vrânceanu et al., 2020).

Also the representativeness of the sample is suggested by the fact that the sample profile matches the statistical population, which is considered a valid argument. (Fonseca and Domingues, 2017).

According to the data provided by INS (National Institute of Statistics), the population of our country in urban areas is predominantly feminized, while people aged between 35-39 and 45-49 years of age have the largest share in the urban population. (https://insse.ro). Our research sample consisted of $36.0 \%$ males and $64.0 \%$ females; majority of the respondents are between 26-45 years old; most of the participants have higher education; $22.8 \%$ of the respondents have a monthly income between 3501-4500 lei (leu is the local currency), 19.1\% are customers with a monthly income between 2501-3500 lei, and $18.0 \%$, with a monthly income between $4501-6000$ lei.

Table 1. The sample structure

\begin{tabular}{|c|c|c|c|}
\hline \multirow[t]{2}{*}{ Item } & \multirow[t]{2}{*}{ Characteristic } & \multicolumn{2}{|c|}{ Internet banking users } \\
\hline & & Frequency & Percent \\
\hline \multirow[t]{2}{*}{ Gender } & Male & 266 & $36.0 \%$ \\
\hline & Female & 472 & $64.0 \%$ \\
\hline \multirow[t]{6}{*}{ Age } & $18-25$ & 98 & $13.3 \%$ \\
\hline & $26-35$ & 238 & $32.2 \%$ \\
\hline & $36-45$ & 239 & $32.4 \%$ \\
\hline & $46-55$ & 112 & $15.2 \%$ \\
\hline & $56-65$ & 47 & $6.4 \%$ \\
\hline & 66 or over & 4 & $.5 \%$ \\
\hline \multirow[t]{3}{*}{ Education } & Secondary school & 119 & $16.1 \%$ \\
\hline & Higher education & 363 & $49.2 \%$ \\
\hline & Postgraduate & 256 & $34.7 \%$ \\
\hline \multirow[t]{6}{*}{ Income } & under 1500 lei & 40 & $5.4 \%$ \\
\hline & 1501-2500 lei & 127 & $17.2 \%$ \\
\hline & 2501-3500 lei & 141 & $19.1 \%$ \\
\hline & 3501-4500 lei & 168 & $22.8 \%$ \\
\hline & 4501-6000 lei & 133 & $18.0 \%$ \\
\hline & 6001 lei and over & 129 & $17.5 \%$ \\
\hline Total & & 738 & $100 \%$ \\
\hline
\end{tabular}

Source: Authors' own research 


\section{Results and discussion Preliminary results}

The Romanian banking sector detains 74.1 percent of the financial sector (2019 Q3). However, despite this prevalent share, the level of financial intermediation is low; the share of total bank assets in GDP is five times lower than the European Union average (2019 Q2) (NBR, 2019). The NBR data for September 2019 (NBR, 2019) reveals that the banks' business model in Romania is generally a traditional one, based on the household loans, representing 53 percent in total credit. The loans denominated in the local currency accounts for 66.6 percent of the stock, suggesting that the foreign-currency risk has decreased. The traditional dimension of the business model developed by the banks in Romania is strengthened by the dominant share of deposits from resident non-government clients in the liability structure (68 percent). The household deposits account for 42 percent in total liabilities.

At-end of 2019 there were 34 credit institutions, among which 27 credit institutions, Romanian legal entities, and 7 branches of foreign credit institutions. A characteristic of the Romanian banking system is the great importance of the credit institutions with a foreign capital majority. Their market share (including branches of foreign credit institutions) accounted for 73.6 percent. The main important banks in Romania, according to their market share, were: (1) Banca Transilvania - 17.72\%; (2) Banca Comercială Română 14.43\%; (3) BRD - Groupe Société Générale - 11.28\%; (4) ING Bank N.V., Amsterdam 9.01\%; (5) UniCredit Bank - 8.99\%; (6) Raiffeisen Bank - 8.66\%; (7) CEC Bank - 6.64\%; (8) Alpha Bank - 3.60\%; (9) OTP Bank - 2.68\%; (10) Garanti Bank - 2.19\% (BNR, 2019).

Since March 2020, COVID-19 has also been spreading across Romania, which, similar to the situation in other countries, has determined the authorities to impose social distancing measures, causing restrictions that affected people and economy. In this context, banks in Romania have continued their activity but they have taken measures to prevent the coronavirus spread.

The key fiscal and monetary measures adopted as response to COVID-19 include government guarantees of 15 billion RON (RON, domestic currency), which represents (1.5\% of 2019 GDP), for loans granted by banks to small and medium enterprises; reducing the monetary policy rate by 0.75 percentage points; use of repo transactions in government securities to provide liquidity to credit institutions (IMF, 2020).

The descriptive statistics corresponding to the univariate type analysis of the research' results has emphasized certain features regarding the consumer behavior in the Romanian retail banking.

Table 2. Definition of research variables and descriptive statistics values

\begin{tabular}{|l|l|l|l|}
\hline \multicolumn{3}{|c|}{ Variables from the tested model } \\
\hline Construct & Item & Scale & Value \\
\hline Perception of COVID 19 & The COVID 19 pandemic affect your lifestyle & 1- to a very low extent & $0.8 \%$ \\
Pandemic influence & & - to a low extent & $3.9 \%$ \\
(PCOV) & $3-$ no-no & $8.8 \%$ \\
& & 4 - to a large extent & $40.9 \%$ \\
& & 5 - to a very large extent & $45.5 \%$ \\
\hline
\end{tabular}




\begin{tabular}{|c|c|c|c|}
\hline \multirow[t]{3}{*}{$\begin{array}{l}\text { Perceived utility of } \\
\text { internet and mobile } \\
\text { banking } \\
\text { (PUIM) }\end{array}$} & $\begin{array}{l}\text { During the COVID19 pandemic the use of } \\
\text { internet and mobile banking services is useful }\end{array}$ & $\begin{array}{l}1 \text { - to a very low extent } \\
2 \text { - to a low extent } \\
3 \text { - no-no } \\
\text { 4- to a large extent } \\
5 \text { - to a very large extent }\end{array}$ & $\begin{array}{l}4.7 \% \\
3.8 \% \\
6.8 \% \\
22.6 \% \\
62.1 \% \\
\end{array}$ \\
\hline & $\begin{array}{l}\text { During the COVID19 pandemic the use of } \\
\text { internet and mobile banking services } \\
\text { increases the quality of my banking services }\end{array}$ & $\begin{array}{l}1 \text { - to a very low extent } \\
2 \text { - to a low extent } \\
3 \text { - no-no } \\
\text { 4- to a large extent } \\
5 \text { - to a very large extent }\end{array}$ & $\begin{array}{l}6.1 \% \\
6.8 \% \\
24.9 \% \\
30.2 \% \\
32.0 \%\end{array}$ \\
\hline & $\begin{array}{l}\text { During the COVID19 pandemic the use of } \\
\text { internet and mobile banking services } \\
\text { increases the efficiency of my banking } \\
\text { services }\end{array}$ & $\begin{array}{l}1 \text { - to a very low extent } \\
2 \text { - to a low extent } \\
3 \text { - no-no } \\
\text { 4- to a large extent } \\
5 \text { - to a very large extent }\end{array}$ & $\begin{array}{l}1.1 \% \\
3.4 \% \\
8.3 \% \\
39.4 \% \\
47.8 \%\end{array}$ \\
\hline $\begin{array}{l}\text { Safety of internet/ } \\
\text { mobile banking use } \\
\text { (SIMB) }\end{array}$ & $\begin{array}{l}\text { The technology used for internet and mobile } \\
\text { banking is reliable }\end{array}$ & $\begin{array}{l}\text { 1- to a very low extent } \\
\text { 2- to a low extent } \\
3 \text { - no-no } \\
\text { 4- to a large extent } \\
5 \text { - to a very large extent }\end{array}$ & $\begin{array}{l}1.1 \% \\
3.9 \% \\
8.5 \% \\
41.6 \% \\
44.9 \%\end{array}$ \\
\hline $\begin{array}{l}\text { Trust in Banks } \\
\text { (TB) }\end{array}$ & $\begin{array}{l}\text { Your current level of trust in banking } \\
\text { institutions (during the COVID19 pandemic) }\end{array}$ & $\begin{array}{ll}\text { 1. Very low } \\
\text { 2. Low } \\
\text { 3. No-no } \\
\text { 4. High } \\
\text { 5. Very high }\end{array}$ & $\begin{array}{l}0.9 \% \\
2.6 \% \\
9.8 \% \\
36.9 \% \\
49.9 \%\end{array}$ \\
\hline $\begin{array}{l}\text { Ease of use of internet } \\
\text { and mobile banking } \\
\text { (EUIM) }\end{array}$ & $\begin{array}{l}\text { You think that the use of internet and mobile } \\
\text { banking services is easy }\end{array}$ & $\begin{array}{l}\text { 1- to a very low extent } \\
\text { 2- to a low extent } \\
3 \text { - no-no } \\
\text { 4- to a large extent } \\
5 \text { - to a very large extent }\end{array}$ & $\begin{array}{l}0.5 \% \\
4.2 \% \\
8.0 \% \\
41.2 \% \\
46.1 \% \\
\end{array}$ \\
\hline $\begin{array}{l}\text { Attitude towards } \\
\text { internet and mobile } \\
\text { banking } \\
\text { (AIMB) }\end{array}$ & $\begin{array}{l}\text { To what extent do you currently trust (during } \\
\text { The COVID19 pandemic) online / mobile } \\
\text { banking services }\end{array}$ & $\begin{array}{l}\text { 1- to a very low extent } \\
\text { 2- to a low extent } \\
\text { 3- no-no } \\
\text { 4- to a large extent } \\
\text { 5- to a very large extent }\end{array}$ & $\begin{array}{l}0.5 \% \\
3.0 \% \\
9.1 \% \\
35.1 \% \\
52.3 \% \\
\end{array}$ \\
\hline $\begin{array}{l}\text { Use of internet and } \\
\text { mobile banking } \\
\text { (UIMB) }\end{array}$ & $\begin{array}{l}\text { Do you currently use of online banking / } \\
\text { mobile banking for various payments, online } \\
\text { purchase of products etc? }\end{array}$ & $\begin{array}{l}\text { Yes } \\
\text { No }\end{array}$ & $\begin{array}{l}88.1 \% \\
11.9 \%\end{array}$ \\
\hline $\begin{array}{l}\text { Banks communication } \\
\text { regarding online } \\
\text { transactions risk } \\
\text { exposure (BCOT) }\end{array}$ & $\begin{array}{l}\text { Do you consider it appropriate at the moment } \\
\text { (during the COVID19 pandemic ) a more } \\
\text { intensive communication from banking } \\
\text { institutions concerning the risks involved in } \\
\text { online banking transactions and the measures } \\
\text { they take to mitigate these risks? }\end{array}$ & $\begin{array}{l}\text { 1. To a very low extent } \\
\text { 2. To a low extent } \\
\text { 3. No -no } \\
\text { 4. To a large extent } \\
\text { 5. To a very large extent }\end{array}$ & $\begin{array}{l}1.6 \% \\
5.4 \% \\
16.4 \% \\
45.1 \% \\
31.4 \%\end{array}$ \\
\hline \multicolumn{4}{|c|}{ Other variables from the research } \\
\hline $\begin{array}{l}\text { Bank headquarter visit } \\
\text { during COVID19 } \\
\text { pandemic }\end{array}$ & $\begin{array}{l}\text { After the establishment of the state of } \\
\text { emergency on March 16, } 2020 \text { (during the } \\
\text { COVID } 19 \text { pandemic) did you visit the } \\
\text { headquarters of any bank agency / branch? } \\
\text { (until current date) }\end{array}$ & $\begin{array}{l}\text { Yes } \\
\text { No }\end{array}$ & $\begin{array}{l}35.2 \% \\
64.8 \%\end{array}$ \\
\hline $\begin{array}{l}\text { Frequency of bank } \\
\text { agencies visits during } \\
\text { COVID19 pandemic }\end{array}$ & $\begin{array}{l}\text { How often did you visit the headquarters of the } \\
\text { banking agencies / branches after the state of } \\
\text { emergency (during the COVID } 19 \text { pandemic)? }\end{array}$ & $\begin{array}{l}\text { never } \\
1 \text { time per month } \\
1 \text { time every } 2 \text { weeks } \\
\text { weekly } \\
\text { more than once a week }\end{array}$ & $\begin{array}{l}57.3 \% \\
25.9 \% \\
14.2 \% \\
1.8 \% \\
0.8 \%\end{array}$ \\
\hline $\begin{array}{l}\text { Frequency of ATM use } \\
\text { during COVID } 19 \\
\text { pandemic }\end{array}$ & $\begin{array}{l}\text { How often do you use bank ATMs in present } \\
\text { (during the COVID } 19 \text { pandemic)? }\end{array}$ & $\begin{array}{l}\text { never } \\
1 \text { time per month } \\
1 \text { time every two weeks } \\
\text { weekly } \\
\text { more than once a week }\end{array}$ & $\begin{array}{l}13.4 \% \\
33.3 \% \\
29.7 \% \\
17.3 \% \\
6.2 \%\end{array}$ \\
\hline
\end{tabular}




\begin{tabular}{|c|c|c|c|}
\hline $\begin{array}{l}\text { Type of operations } \\
\text { performed at ATMs } \\
\text { during COVID } 19 \\
\text { pandemic }\end{array}$ & $\begin{array}{l}\text { What kind of operations do you perform at } \\
\text { ATMs? }\end{array}$ & $\begin{array}{l}\text { cash withdrawal } \\
\text { cash deposit } \\
\text { payment for utilities } \\
\text { bank transfer } \\
\text { foreign exchange } \\
\end{array}$ & $\begin{array}{l}92.3 \% \\
29.8 \% \\
14.8 \% \\
11.0 \% \\
2.6 \% \\
\end{array}$ \\
\hline $\begin{array}{l}\text { Use of online banking / } \\
\text { mobile banking } \\
\text { services before the } \\
\text { COVID } 19 \text { pandemic }\end{array}$ & $\begin{array}{l}\text { Do you use the online banking / mobile } \\
\text { banking services before the COVID } 19 \\
\text { pandemic broke out / declared a state of } \\
\text { emergency in connection with the COVID } 19 \\
\text { pandemic? }\end{array}$ & $\begin{array}{l}\text { Yes } \\
\text { No }\end{array}$ & $\begin{array}{l}81.3 \% \\
18.7 \%\end{array}$ \\
\hline $\begin{array}{l}\text { Perception about the } \\
\text { need for banking } \\
\text { institutions to offer } \\
\text { online courses / } \\
\text { tutorials to familiarize } \\
\text { customers with the use } \\
\text { of digital channels }\end{array}$ & $\begin{array}{l}\text { Do you currently consider it appropriate } \\
\text { (during the COVID19 pandemic) for banking } \\
\text { institutions to offer online courses / tutorials } \\
\text { to familiarize you with the use of digital } \\
\text { channels? }\end{array}$ & $\begin{array}{l}1 \text { - to a very low extent } \\
2 \text { - to a low extent } \\
3 \text { - no-no } \\
4 \text { - to a large extent } \\
5 \text { - to a very large extent }\end{array}$ & $\begin{array}{l}14.4 \% \\
16.1 \% \\
18.4 \% \\
37.3 \% \\
13.8 \%\end{array}$ \\
\hline $\begin{array}{l}\text { Perception about the } \\
\text { need for banking } \\
\text { institutions to offer } \\
\text { financial education } \\
\text { courses / tutorials }\end{array}$ & $\begin{array}{l}\text { Do you consider it opportune for banking } \\
\text { institutions to offer online financial education } \\
\text { courses / tutorials at present (during the } \\
\text { COVID19 pandemic)? }\end{array}$ & $\begin{array}{l}1 \text { - to a very low extent } \\
2 \text { - to a low extent } \\
3 \text { - no-no } \\
4 \text { - to a large extent } \\
5 \text { - to a very large extent }\end{array}$ & $\begin{array}{l}6.1 \% \\
7.5 \% \\
29.5 \% \\
36.9 \% \\
28.0 \% \\
\end{array}$ \\
\hline $\begin{array}{l}\text { Type of banking } \\
\text { service used during } \\
\text { COVID } 19 \text { pandemic }\end{array}$ & $\begin{array}{l}\text { Please specify which of the following are the } \\
\text { banking services you are currently using } \\
\text { (during the COVID } 19 \text { pandemic)? }\end{array}$ & $\begin{array}{l}\text { checking account balance } \\
\text { transaction history } \\
\text { utility payments } \\
\text { making bank transfers } \\
\text { obtaining loans online } \\
\text { online shopping } \\
\text { payment of installments due } \\
\text { on loans held } \\
\text { information on banking } \\
\text { products and services } \\
\text { banking financial consulting }\end{array}$ & $\begin{array}{l}86.7 \% \\
69.4 \% \\
70.3 \% \\
61.7 \% \\
0.3 \% \\
68.0 \% \\
40.1 \% \\
13.6 \% \\
4.3 \% \\
\end{array}$ \\
\hline $\begin{array}{l}\text { Perception about the } \\
\text { benefits of current } \\
\text { system of postponing } \\
\text { the payment of } \\
\text { installments due to } \\
\text { contracted loans }\end{array}$ & $\begin{array}{l}\text { To what extent do you consider that the current } \\
\text { system of postponing the payment of } \\
\text { installments due to contracted loans proposed } \\
\text { by the authorities is beneficial / advantageous } \\
\text { for you? }\end{array}$ & $\begin{array}{l}1 \text { - to a very low extent } \\
2 \text { - to a low extent } \\
3 \text { - no-no } \\
4 \text { - to a large extent } \\
5 \text { - to a very large extent }\end{array}$ & $\begin{array}{l}35.2 \% \\
12.5 \% \\
36 \% \\
9.5 \% \\
6.8 \%\end{array}$ \\
\hline $\begin{array}{l}\text { Intention to access } \\
\text { consumer loans }\end{array}$ & $\begin{array}{l}\text { Do you intend to access consumer loans in the } \\
\text { near future (during the COVID19 pandemic)? }\end{array}$ & $\begin{array}{l}\text { Yes } \\
\text { No }\end{array}$ & $\begin{array}{l}12.1 \% \\
87.9 \%\end{array}$ \\
\hline $\begin{array}{l}\text { Intention to access } \\
\text { loans for the purchase } \\
\text { of a home }\end{array}$ & $\begin{array}{l}\text { Do you intend to access loans for the purchase } \\
\text { of a home in the near future (during the } \\
\text { COVID19 pandemic)? }\end{array}$ & $\begin{array}{l}\text { Yes } \\
\text { No }\end{array}$ & $\begin{array}{l}12.5 \% \\
87.5 \%\end{array}$ \\
\hline $\begin{array}{l}\text { Intention to refinance } \\
\text { existing loans }\end{array}$ & $\begin{array}{l}\text { Do you intend to refinance existing loans in the } \\
\text { near future (during the COVID19 pandemic)? }\end{array}$ & $\begin{array}{l}\text { Yes } \\
\text { No }\end{array}$ & $\begin{array}{l}91.5 \% \\
8.5 \%\end{array}$ \\
\hline $\begin{array}{l}\text { Intention to set up } \\
\text { bank deposits }\end{array}$ & $\begin{array}{l}\text { Do you intend to set up bank deposits in the } \\
\text { near future (during the CoVID19 pandemic)? }\end{array}$ & $\begin{array}{l}\text { Yes } \\
\text { No }\end{array}$ & $\begin{array}{l}28.9 \% \\
71.1 \% \\
\end{array}$ \\
\hline $\begin{array}{l}\text { Intention to invest in } \\
\text { stocks, bonds or fund } \\
\text { units }\end{array}$ & $\begin{array}{l}\text { Do you intend to invest in the near future } \\
\text { (during the COVID19 pandemic) in stocks, } \\
\text { bonds or fund units? }\end{array}$ & $\begin{array}{l}\text { Yes } \\
\text { No }\end{array}$ & $\begin{array}{l}13.8 \% \\
86.2 \%\end{array}$ \\
\hline $\begin{array}{l}\text { Perception about bank } \\
\text { customer social policy }\end{array}$ & $\begin{array}{l}\text { Do you think that banks take into account your } \\
\text { most important interests? }\end{array}$ & $\begin{array}{l}\text { 1- to a very low extent } \\
\text { 2- to a low extent } \\
\text { 3- no-no } \\
\text { 4- to a large extent } \\
\text { 5- to a very large extent }\end{array}$ & $\begin{array}{l}28.6 \% \\
27.6 \% \\
33.3 \% \\
7.7 \% \\
2.7 \% \\
\end{array}$ \\
\hline
\end{tabular}

Source: Authors' own research 
Visits to banks during the pandemic period

The results of the survey confirm our assumption regarding the limitation of customers' visits to the physical locations of their bank. Almost $58.0 \%$ of the respondents have never visited their bank during the pandemic while $25.9 \%$ of the respondents have visited their bank only once a month. Nevertheless, majority of the participants has used the automatic teller machines (ATMs) in this period: $33.3 \%$ of them once a month, $29.7 \%$, once every two weeks, $17.3 \%$, once a week and $6.2 \%$ of the respondents even more often than once a week. The most accessed services through ATMs are cash withdrawals $(92.3 \%$ of the respondents) and cash deposit (29.8\% of the respondents), which indicates that, even in the metropolitan area, the use of cash is still important in Romania.

\section{Online/mobile banking use}

Online or mobile banking were widely used even before the pandemic $(81.3 \%$ of the respondents) and the difference after the outbreak of the coronavirus pandemic is small in terms of modified behavior. These results are consistent with the NBR Financial Stability Report, December 2019, which mentions that the digital banking services in the Romanian banking system have been promoted even until the outbreak of the COVID-19 crisis, in order to optimize operational costs.

Internet and mobile banking is easy to use for the vast majority of consumers. Confidence in technology is quite high as well; $41.6 \%$ of the respondents trust technology to a great extent, and $44.9 \%$ of them, to a very great extent. The technology is very useful and consumers believe that technology helps increase the efficiency of banking services (to a greater extent than the quality of services).

\section{Trust in banking system}

The degree of trust in banks is quite high; $36.9 \%$ of the respondents consider they have great confidence in banks, while $49.9 \%$ of them trust banks to great extent. From this point of view, our survey indicates a better situation than the results of another survey performed by the NBR. The NBR survey on the costumers' confidence in the Romanian banking system (NBR, 2019, p. 58) reveals that, from the banks' point of view, the customers' confidence is "moderate". The banking system considers that the negative information reflected in the media and potential rumors are the main factors affecting customers' confidence. In addition, confidence is highly influenced by the customers' perception regarding the transparency of interest rates and banking commissions. The negative impact of advance in digitalization and the illicit actions developed by banks are also mentioned by the survey's results. Surprisingly, a worsening in the prudential framework of banks, in terms of liquidity and solvency indicators, is viewed as a less important threat to customers' confidence (NBR, 2019, p. 58). This might suggest that, during the pandemic period, the perception of customers towards banks in Romania in terms of confidence has improved. However, from a nuanced perspective, according to our survey, $56.2 \%$ of the respondents agree that banks consider their most important interests only to a small extent or to a very small extent.

\section{Online/tutorial courses}

Courses and tutorials for familiarization with the use of digital channels are imperatively required by $51.1 \%$ of the respondents, which denotes the necessity of organizing such 
courses. Majority of the respondents - 76.5\% - require communication on the risks involved in online banking transactions and measures to mitigate these risks.

Online courses/tutorials related to financial education denotes also pretty much interest from the respondents, with $64.9 \%$ positive answers.

\section{Moratorium on credits}

Similar to other countries, Romania has adopted the legislative framework through which individual debtors affected by the COVID-19 pandemic can benefit from the suspension of the payment of installments due to their loans for a period between one month and 9 months that cannot exceed 31 December 2020. The deadline for submitting the application for the credit installments suspension was 15 June 2020 (Guvernul României, 2020). According to a press release issued by the Romanian Association of Banks on May 18, 2020, 303,000 individual customers requested the suspension of the payment of loan installments, which means about $20 \%$ of loans granted to individuals (ARB, 2020).

Our survey also reveals a result close to the figure mentioned above; only $16.3 \%$ of the participants consider that this moratorium on credits is advantageous for them.

\section{Deposits}

According to the NBR data (NBR, 2020), the deposits of households denominated both in domestic currency (RON) and foreign currency increased in April 2020 compared to March 2020. The RON-denominated deposits increased by 3.4 percent while the forexdenominated deposits advanced by 1.4 percent (when expressed in RON). On an annual basis, the increase of the household deposits is even bigger - the RON-denominated deposits increased by 12.2 percent in April 2020 versus the year-ago period and the forexdenominated deposits, by $18.6 \%$ (when expressed in RON).

According to our survey, about $30 \%$ of respondents have the intention to constitute bank deposits in the near future, which could reflect lack of liquidity of some of the households investigated in the moment of research.

\section{Credits}

Majority of the participants - over $87.0 \%$ - mention that they will not intent to get a bank loan - consumer credit or mortgage credit - during the pandemic period. The results are in line with recent statistics issued by the NBR. At end of April 2020, the RON-denominated loans granted to households decreased by 0.2 percent from March 2020 and the forexdenominated loans granted to households went down by 0.4 percent (NBR, 2020).

\section{Validation of the research model}

We began to run the data analysis of the 738 validated received questionnaires using the SPSS version 26.0 software. In order to test the advanced hypotheses and the relationship among the considered variables for the conceptual model, we implemented a regression equation for every hypothesis. Thus, the regression models analyzed are as follows:

$\mathrm{Y}=\mathrm{B}_{0}+\mathrm{B}_{1} \mathrm{X}_{1}+\mathcal{\Sigma}$. The results can be observed in the following table. 
Table3. Values of regression models

\begin{tabular}{|l|l|l|r|r|r|r|r|r|r|r|l|}
\hline Hypotheses & correlation & $\mathrm{R}$ & $\begin{array}{l}\mathrm{R} \\
\text { Square }\end{array}$ & $\begin{array}{l}\text { Adjusted } \\
\text { R } \\
\text { Square }\end{array}$ & $\begin{array}{l}\text { Std. } \\
\text { Error of } \\
\text { the } \\
\text { Estimate }\end{array}$ & $\begin{array}{l}\text { R } \\
\text { Square } \\
\text { Change }\end{array}$ & F Change & df & $\begin{array}{l}\text { Sig. F } \\
\text { Change }\end{array}$ & $\begin{array}{l}\text { Durbin- } \\
\text { Watson }\end{array}$ & $\begin{array}{l}\text { Hypothesis } \\
\text { Testing }\end{array}$ \\
\hline $\mathrm{H}_{1}$ & $\begin{array}{l}\text { PCOV -> } \\
\text { PUIM }\end{array}$ & .944 & .891 & .891 & .278 & .891 & 6026.907 & 736 & .000 & 1.869 & supported \\
\hline $\mathrm{H}_{2}$ & $\begin{array}{l}\text { PUIM -> } \\
\text { AIMB }\end{array}$ & .849 & .721 & .721 & .428 & .721 & 1901.735 & 736 & .000 & 1.604 & supported \\
\hline $\mathrm{H}_{3}$ & $\begin{array}{l}\text { PCOV -> } \\
\text { AIMB }\end{array}$ & .839 & .704 & .704 & .441 & .704 & 1753.440 & 736 & .000 & 1.464 & supported \\
\hline $\mathrm{H}_{4}$ & $\begin{array}{l}\text { PCOV -> } \\
\text { EUIM }\end{array}$ & .871 & .759 & .758 & .405 & .759 & 2312.866 & 736 & .000 & 1.461 & supported \\
\hline $\mathrm{H}_{5}$ & $\begin{array}{l}\text { EUIM -> } \\
\text { AIMB }\end{array}$ & .789 & .623 & .622 & .498 & .623 & 1214.138 & 736 & .000 & 1.512 & supported \\
\hline $\mathrm{H}_{6}$ & $\begin{array}{l}\text { PCOV -> } \\
\text { TB }\end{array}$ & .844 & .712 & .712 & .443 & .712 & 1822.436 & 736 & .000 & 1.454 & supported \\
\hline $\mathrm{H}_{7}$ & $\begin{array}{l}\text { PCOV -> } \\
\text { SIMB }\end{array}$ & .851 & .725 & .724 & .447 & .725 & 1937.988 & 736 & .000 & 1.900 & supported \\
\hline $\mathrm{H}_{8}$ & $\begin{array}{l}\text { SIMB -> } \\
\text { TB }\end{array}$ & .758 & .575 & .574 & .539 & .575 & 994.601 & 736 & .000 & 1.714 & supported \\
\hline $\mathrm{H}_{9}$ & $\begin{array}{l}\text { TB -> } \\
\text { AIMB }\end{array}$ & .851 & .724 & .724 & .426 & .724 & 1932.955 & 736 & .000 & 1.836 & supported \\
\hline $\mathrm{H}_{10}$ & $\begin{array}{l}\text { SIMB -> } \\
\text { AIMB }\end{array}$ & .821 & .675 & .674 & .462 & .675 & 1526.562 & 736 & .000 & 1.741 & supported \\
\hline $\mathrm{H}_{11}$ & $\begin{array}{l}\text { AIMB -> } \\
\text { UIMB }\end{array}$ & .720 & .518 & .518 & .225 & .518 & 792.542 & 736 & .000 & 1.749 & supported \\
\hline $\mathrm{H}_{12}$ & $\begin{array}{l}\text { AIMB -> } \\
\text { BCOT }\end{array}$ & .869 & .755 & .754 & .452 & .755 & 2262.691 & 736 & .000 & 1.988 & supported \\
\hline
\end{tabular}

Source: Authors' own research

The values of $\mathrm{R}$ are higher than .7 for all the considered correlations, which indicates the positive meaning of the relationship among the observed and predicted values of the dependent variables, providing a first indication of the consistency of the considered models.

Taking into account the value of $\mathrm{R}$ Square, it can be stated that most of the variation of the causal variables can be explained in the case of the PUIM variation, for which $89.1 \%$ of the variation is explained by the variation of the causal variable and PCOV and only $10.9 \%$ being due to the variation of the residual variable $\varepsilon$.

The equality or proximity of the two values (adjusted R Square and R Square) offer the possibility to generalize the regression model to the entire research population (Field, 2009). Equality is found in the case of the PCOV $>$ PUIM, PCOV $>$ AIMB, PUIM $>$ AIMB, $\mathrm{PCOV}>\mathrm{TB}, \mathrm{TB}>\mathrm{AIMB}, \mathrm{AIMB}>\mathrm{UIMB}$ relationships, and some differences are found in the case of the PCOV $>$ EUIM, EUIM $>$ AIMB, PCOV $>$ SIMB, SIMB $>$ TB, SIMB $>$ AIMB, AIMB $>$ BCOT relationships, where the difference is .001 .

In this case, if the regression models would extend to the entire research population, the variation of the dependent variable would decrease by 1 percent in the case of PCOV in relation to the causal variables EUIM and SIMB.

The values in the $\mathrm{F}$ Change column are statistically significant, with a probability of .000 (Sig. F Change) that these values are due to chance and not to a real link. 
Durbin-Watson provides information on the hypothesis of lack of autocorrelation of residual variables. (Di Guardo et al., 2009).

A revision of the regression model is recommended if the value of the DurbinWatson statistic is below 1 or exceeds 3 and the model can be kept if the Durbin-Watson value is close to 2 (Field, 2009; Wooldridge, 2009). In this case, the values for all the regression models are above 1.5 , which means that the regression models are valid in terms of the lack of autocorrelation of the residual variables.

As illustrated in the table 3 , all the estimated parameters are positive, which means there is a direct relationship between the independent variables and the dependent variables. It is also noticeable that the greatest influence is of PCOV on PUIM because B = .944 - a change with one unit of PCOV determines a PUIM increases by .944 units.

Table 4. Unstandardized and Standardized Coefficients for the regression models

\begin{tabular}{|c|c|c|c|c|c|c|c|c|}
\hline \multirow[t]{2}{*}{ Model } & & \multicolumn{2}{|c|}{$\begin{array}{c}\text { Unstandardized } \\
\text { Coefficients }\end{array}$} & \multirow{2}{*}{$\begin{array}{c}\begin{array}{c}\text { Standardized } \\
\text { Coefficients }\end{array} \\
\text { Beta }\end{array}$} & \multirow[t]{2}{*}{ t-value } & \multirow[t]{2}{*}{ Sig. level } & \multicolumn{2}{|c|}{$\begin{array}{l}95.0 \% \text { Confidence } \\
\text { Interval for B }\end{array}$} \\
\hline & & B & Std. Error & & & & $\begin{array}{l}\text { Lower } \\
\text { Bound }\end{array}$ & $\begin{array}{l}\text { Upper } \\
\text { Bound }\end{array}$ \\
\hline \multirow[t]{2}{*}{ PCOV -> PUIM } & (Constant) & .262 & .053 & & 4.941 & .000 & .158 & .366 \\
\hline & PCOV & .946 & .012 & .944 & 77.633 & .000 & .922 & .970 \\
\hline \multirow[t]{2}{*}{ PUIM -> AIMB } & (Constant) & .846 & .082 & & 10.310 & .000 & .685 & 1.007 \\
\hline & PUIM & .817 & .019 & .849 & 43.609 & .000 & .781 & .854 \\
\hline \multirow[t]{2}{*}{ PCOV -> AIMB } & (Constant) & .905 & .084 & & 10.767 & .000 & .740 & 1.069 \\
\hline & PCOV & .809 & .019 & .839 & 41.874 & .000 & .772 & .847 \\
\hline \multirow[t]{2}{*}{ PCOV -> EUIM } & (Constant) & .633 & .077 & & 8.194 & .000 & .482 & .785 \\
\hline & PCOV & .855 & .018 & .871 & 48.092 & .000 & .820 & .890 \\
\hline \multirow[t]{2}{*}{ EUIM -> AIMB } & (Constant) & 1.039 & .097 & & 10.716 & .000 & .849 & 1.229 \\
\hline & EUIM & .775 & .022 & .789 & 34.844 & .000 & .731 & .819 \\
\hline \multirow[t]{2}{*}{ PCOV $\rightarrow$ TB } & (Constant) & .780 & .085 & & 9.227 & .000 & .614 & .946 \\
\hline & PCOV & .830 & .019 & .844 & 42.690 & .000 & .792 & .869 \\
\hline \multirow[t]{2}{*}{ PCOV -> SIMB } & (Constant) & .568 & .085 & & 6.653 & .000 & .400 & .735 \\
\hline & PCOV & .864 & .020 & .851 & 44.023 & .000 & .826 & .903 \\
\hline \multirow[t]{2}{*}{ SIMB -> TB } & (Constant) & 1.196 & .101 & & 11.838 & .000 & .998 & 1.395 \\
\hline & SIMB & .735 & .023 & .758 & 31.537 & .000 & .689 & .781 \\
\hline \multirow[t]{2}{*}{ TB $->$ AIMB } & (Constant) & .751 & .083 & & 9.001 & .000 & .588 & .915 \\
\hline & TB & .834 & .019 & .851 & 43.965 & .000 & .797 & .872 \\
\hline \multirow[t]{2}{*}{ SIMB -> AIMB } & (Constant) & 1.037 & .087 & & 11.972 & .000 & .867 & 1.207 \\
\hline & SIMB & .781 & .020 & .821 & 39.071 & .000 & .741 & .820 \\
\hline \multirow[t]{2}{*}{ AIMB -> UIMB } & (Constant) & .625 & .045 & & 13.760 & .000 & .535 & .714 \\
\hline & AIMB & .288 & .010 & .720 & 28.152 & .000 & .268 & .308 \\
\hline \multirow[t]{2}{*}{ AIMB ->BCOT } & (Constant) & 6.948 & .091 & & 76.261 & .000 & 6.769 & 7.127 \\
\hline & AIMB & -.978 & .021 & -.869 & -47.568 & .000 & -1.018 & -.938 \\
\hline
\end{tabular}

Source: Authors' own research

Because the standard error associated with the estimated parameters is lower, their prediction accuracy is high. The regression models are characterized by low standard errors for each of the estimated parameters; therefore, they can be considered consistent in terms of predictive capacity (figure 2). 


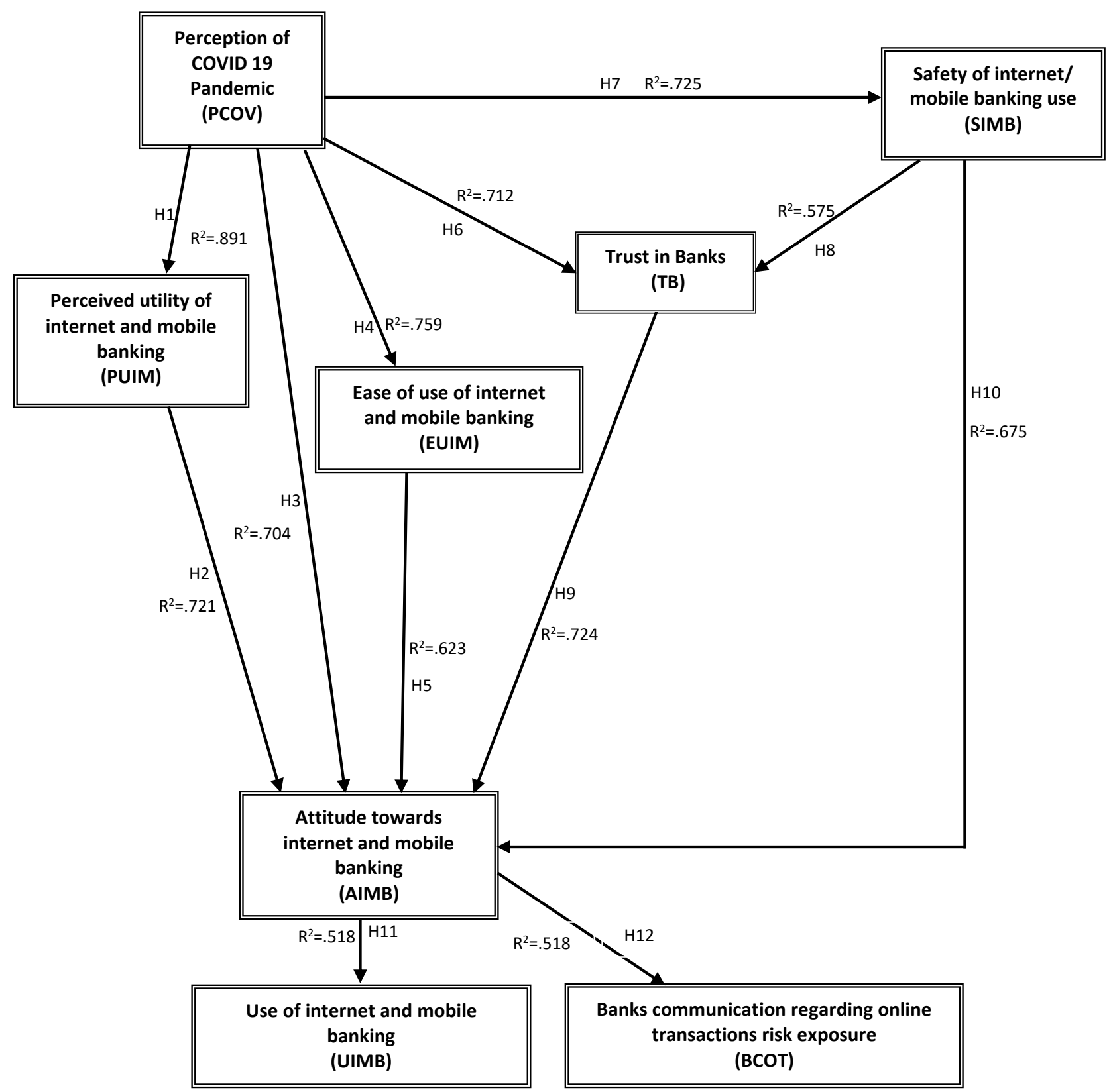

Figure 2. The research validated model

Source: Authors' own research

The table 4 indicates that all the estimated parameters in the case of the t-Student test differ significantly from 0, with a probability of .000 (Sig.) that the value of the tStudent test is due to chance. Regarding the t-Student test, the maximum value is found for the PCOV regression parameter, which has the greatest influence on the dependent variable PUIM (77.633).

The confidence intervals determined for the parameters of the considered regression models have a short length, confirming the consistency of the parameters. The regression models do not need to be revised, being valid, because the confidence intervals 
do not contain the value 0 , which means that the parameters of the regression equations for the sample considered took only positive values.

Taking into account the above results, we can ascertain that the proposed theoretical model was confirmed and all the advanced hypotheses were validated. Still, if we consider the direct relationship between PCOV (customers' perceptions of COVID-19 pandemic) and variables PUIM (Perceived utility of internet and mobile banking during the COVID-19 pandemic), EUIM (Ease of use of internet and mobile banking), TB (trust in banks), SIMB (Safety of internet/ mobile banking use), we can observe a stronger influence, with $\mathrm{R}$ squared ranging from .776 to .885. This means that as consumers become more aware of the effects of the pandemic on their own lifestyle, the consumption behavior of mobile/internet banking services also reflect this influence. It is noticeable the fact that the changing perception about the lifestyle modification under the COVID-19 pandemic conditions does not alter the trust in banks; on the contrary, customers are ready to invest more trust into the banks. As we can observe, the lifestyle changes imply more willingness to trust the safety of internet and mobile banking services, a positive perception about the ease of use of these new technologies, and the most powerful effect, the raise of perceived utility of internet and mobile banking during the COVID-19 pandemic. If we separately analyze the direct relationship between PCOV and AIMB (Attitude towards internet and mobile banking), it appears that the value of R squared is weaker -.556. This means that the rising awareness about changes in lifestyle has a positive correlation with the changing attitude about mobile/internet banking services, but not with the same intensity compared to others relationships. In fact, the variance attitude is influenced by all the others variables in a "splited" manner.

The trust in banks (TB) is also influenced by the perception on safety of mobile/internet banking services. All the variables - PUIM, EUIM, TB, SIMB - are mediators for the PCOV regarding its influence on the attitude towards mobile and internet banking services utilization during the pandemic.

Finally, the correlation between the UIMB (Use of internet and mobile banking) and consumers' perception of COVID-19 pandemic is mediated by all the other variables taken into consideration being a positive one. Actually, Romanian customers use mobile/internet banking services as a result of usefulness and perceived ease of use, which is in accordance with the Technology Acceptance Model theory and other nowadays research, as we indicated at the Research Hypothesis and the proposed model development section. In addition, the special emphasis on trust in banks variable underlines its importance for consumer behavior in banking services.

The attitude towards internet and mobile banking (AIMB) and the banks communication regarding online transactions risk exposure related to mobile and internet banking services use (BCOT) have a direct but negative correlation. Consumers that have more confidence in using mobile and internet banking show less interest in additional efforts of banks to communicate and minimize the risks related to mobile/internet banking services.

As the attitude of consumers towards internet and mobile banking services becomes more and more positive - meaning that if the trust on internet and mobile banking services is greater - their perception about the need to develop the bank communication regarding online transactions risk exposure is negative. Consumers consider that banks do not need 
to communicate more intensively information regarding possible risks about online and mobile transactions.

\section{Conclusions and proposals}

The research shows that the degree of mobile/internet banking services consumption of the respondents has raised during the pandemic in comparison with the period before the pandemic.

Banks managers should take into consideration in the following post COVID -19 pandemic stage to closely monitor the needs and perception of customers because it is very possible that a large amount of them will continue to use this new interface despite the recovering of the bank's full functionality with traditional banking.

The results of the survey indicate the need to intensify the efforts of Romanian banks to offer financial education courses to all categories of customers - young, in the middle stage of life or even in old age. Moreover, in the context of the pandemic, the banks' efforts in this direction acquire new dimensions, as they should be predominantly performed online, which also implies the increase of users' digital skills. Against this background, offering online tutorials to familiarize customers with the use of digital channels is a necessity, especially for customers with few skills in the field or for those who are reluctant to use such alternatives. As the survey indicates, the retail-banking customers in Romania still attach importance to cash extracted from ATMs. Therefore, banks should design marketing programs to promote the use of online channels. For example, partnerships with Fintech should be opportunities to provide appropriate digital solutions for the profile of the retail consumer in Romanian banking sector.

In order to increase confidence in online banking, banks should also improve communication with customers, highlighting the benefits they offer, but also the measures they take to increase the security of online transactions and reduce risks. In our opinion, the management of Romanian banks should design new products to increase the attractiveness of the saving process, given the current low level of interest rates. Another direction that banks should follow refers to credit products. In the conditions of major uncertainty generated by the COVID-19 crisis, it is desirable that banks meet customer requirements and demonstrate flexibility in negotiating lending and refinancing conditions.

The present research was mainly an exploratory one that investigated perceptions upon a phenomenon never seen before that has no prediction or previous record available in terms of consumer behavior. The mechanism of adopting new technologies as a mass consumption feature has to be carefully tested in order to be fully explained and predicted. From this point of view, our research just measured on a limited scale some of the effects that could be easily apprehended by the individuals. Other future research has to combine a qualitative approach with a more elaborated quantitative one in terms of sample representativeness. The research should investigate the impact on a long run of the mass adoption of internet and mobile banking services on the consumer behavior of other products or services that are dependent of the digital channels and easily integrated with electronic banking ones. 


\section{References}

Adapa, S., Roy, S.K., (2017). Consumers' post-adoption behaviour towards Internet banking: empirical evidence from Australia. Behaviour \& Information Technology, 36(9), 970983. https://doi.org/10.1080/0144929X.2017.1319498.

Anneli Järvinen, R., (2014). Consumer trust in banking relationships in Europe. International Journal of Bank Marketing, 32(6), 551-566. https://doi.org/10.1108/IJBM-08-2013-0086.

ARB - Asociaţia Română a Băncilor, (2020). Băncile din România au soluţionat deja 83\% din cele 317.000 de solicitări de suspendare primite de la clienţi, press release, București, 18 May, Retrieved from https://www.arb.ro/wpcontent/uploads/comunicat-18.05.2020.pdf.

Auer, R., Cornelli, G., Frost, J., (2020). Covid-19, cash, and the future of payments, BIS Bulletin, 3, Retrieved from https://www.bis.org/publ/bisbull03.pdf.

Bank of England, (2020). Bank of England measures to respond to the economic shock from Covid-19, Retrieved from https://www.bankofengland.co.uk/news/2020/march/boe-measures-to-respondto-the-economic-shock-from-covid-19.

BCBS - Basel Committee on Banking Supervision, (2020). Measures to reflect the impact of Covid-19, Bank for international Settlements, Retrieved from https://www.bis.org/bcbs/publ/d498.pdf.

Bichi, C., (2020). Coronavirusul şi moratoriile bancare din unele ţări europene. Update!, opiniiBNR.ro, Retrieved from http://www.opiniibnr.ro/index.php/macroeconomie/380-coronavirusul-simoratoriile-bancare-din-unele-tari-europene.

BNR - Banca Naţională a României, (2019). Raport anual 2019, Retrieved from https://www.bnr.ro/DocumentInformation.aspx?idDocument=34472\&idInfoClass= 3043.

Bratianu, C., Nestian, A.S., Tita, S.M., Voda, A.I., Guta, A.L. (2020a). The impact of knowledge risk on sustainability of firms. Amfiteatru Economic, 22(55), 639-652.

Bratianu, C., Prelipcean, G., Bejinaru, R. (2020b). Exploring the latent variables which support SMEs to become learning organizations. Management \& Marketing. Challenges for the Knowledge Society, 15(2), 154-171.

Buehler, K., Conjeaud, O., Giudici, V., Samandari, H., Serino, L., Vettori, M., Webanck, L., White, O., (2020). Leadership in the time of coronavirus: COVID-19 response and implications for banks, McKinesy\&Company, Retrieved from https://www.mckinsey.com/industries/financial-services/our-insights/leadershipin-the-time-of-coronavirus-covid-19-response-and-implications-for-banks.

Cătoiu, I., Gârdan, D.A., Geangu, I.P., (2012). Customer loyalty - specific features of retail activity in Bucharest. Annales Universitatis Apulensis Series Oeconomica, 14(1), 278-285.

Celic, D., Draskovic, Z., Uzleac Z. \& Petrov, V. ( 2018). Differences in attitudes toward internet usage: Empirical study from Serbia. Strategic Management, 23(3), 17-24. 
Coelho, R., Prenio, J., (2020). Covid-19 and operational resilience: addressing financial institutions' operational challenges in a pandemic, FSI Briefs, 2, Bank for International Settlements, Retrieved from https://www.bis.org/fsi/fsibriefs2.pdf.

Craven, M., Liu, L., Mysore, M., Wilson, M., (2020). COVID-19: Implications for business, McKinesy\&Company, Retrieved from https://www.mckinsey.com/businessfunctions/risk/our-insights/covid-19-implications-for-business

Crăciun, L., Năstase, M., Stamule, T., Vizitiu, C., (2015). Leadership in Romanian small to medium enterprises. Sustainability, 7(4), 4183-4198. doi:10.3390/su7044183.

Di Guardo, M.C., Pinna, R., Zaru, D. (Eds.), (2009). Per lo sviluppo, la competitività e l'innovazione del sistema economico. Il contributo degli studi di Organizzazione Aziendale: Il contributo degli studi di Organizzazione Aziendale. Milano: FrancoAngeli.

Dima, A.M., Begu, L., Vasilescu, M.D., Maassen, M.A., (2018). The relationship between the knowledge economy and global competitiveness in the European Union. Sustainability, 10(6), 1706, 1-15. https://doi.org/10.3390/su10061706.

Dincă, V.M., Dima, A.M., Rozsa, Z., (2019). Determinants of cloud computing adoption by Romanian SMEs in the digital economy. Journal of Business Economics and Management, 20(4), 798-820. https://doi.org/10.3846/jbem.2019.9856.

Drehmann, M., Farag, M., Tarashev, N., Tsatsaronis, K., (2020). Buffering Covid-19 losses the role of prudential policy, BIS Buletin, 9, Retrieved from https://www.bis.org/publ/bisbull09.pdf.

eMarketer, (2020). The biggest business impacts of the coronavirus pandemic, Retrieved from https://www.emarketer.com/content/the-biggest-business-impacts-of-thecoronavirus-pandemic-according-to-business-insider-intelligence.

Field, A., (2009). Discovering Statistics Using IBM SPSS Statistics. 5th Edition, California: Sage Publishing.

Finextra, (2020). Coronavirus: DBS pushes 'contact free' digital banking, Retrieved from https://www.finextra.com/newsarticle/35366/coronavirus-dbs-pushes-contactfree-digital-banking.

Fonseca, L.M., Domingues, J.P., (2017). How to succeed in the digital age? Monitor the organizational context, identify risks and opportunities, and manage change effectively. Management \& Marketing. Challenges for the Knowledge Society, 12(3), 443-455. https://doi.org/10.1515/mmcks-2017-0027.

Gârdan, D.A., Geangu, I.P., Roșu, A.M., (2011). Marketing research regarding mobile marketing implications for Romanian services consumers. International Conference on Business Excellence, 1, 229-232.

Gheorghiu, R., Andreescu, L., Zulean, M., Curaj, A., (2017). Entrepreneurial discovery as a foresight for smart specialization: Trade-offs of inclusive and evidence-based consensus. Advances in the Theory and Practice of Smart Specialization, 319-344. https://doi.org/10.1016/B978-0-12-804137-6.00014-0.

Guvernul României, (2020). Ordonanță de urgenţă nr. 37 din 30 martie 2020 privind acordarea unor facilităţi pentru creditele acordate de instituţii de credit şi instituţii financiare nebancare anumitor categorii de debitori, Monitorul Oficial nr. 261 din 30 martie 2020. 
Hadad, S., Brătianu, C., (2019). Dematerialization of banking products and services in the digital era. Management \& Marketing. Challenges for the Knowledge Society, 14(3), 318-337. https://doi.org/10.2478/mmcks-2019-0023.

Hoe, L.K., (2020). COVID-19: opportunities and challenges for digital banks, PWC Malaysia, Retrieved from https://www.pwc.com/my/en/perspective/digital/200408-pwcblog-covid-19-opportunities-challenges-digital-banks.html.

IMF - International Monetary Fund, (2020). Global Financial Stability Report: Markets in the Time of COVID-19. Retrieved from https://www.imf.org/en/Publications/GFSR/Issues/2020/04/14/global-financialstability-report-april-2020.

IMF - International Monetary Fund, (2020). Policy responses to COVID-19, Romania, Retrieved from https://www.imf.org/en/Topics/imf-and-covid19/PolicyResponses-to-COVID-19\#I.

INS (National Institute of Statistics) https://insse.ro/cms/ro/search/node/populatia\%20romaniei\%20pe\%20localitati

Lewis, J., (2020). COVID-19 Insights - Emerging Risks, KPMG International Cooperative, Retrieved from https://home.kpmg/xx/en/home/insights/2020/04/covid-19insights-emerging-risks.html.

Lewrick, U., Schmieder, C., Sobrun, I., Takáts, E., (2020). Releasing bank buffers to cushion the crisis - a quantitative assessment, BIS Bulletin, 11, Retrieved from https://www.bis.org/publ/bisbull11.pdf.

Malhotra, N.K., (2019). Marketing Research: An Applied Orientation, seventh edition, Harlow: Pearson Education Limited.

McCarty, B., (2020). Managing customer relationships in the time of COVID-19, BAI. Banking Strategies, Retrieved from https://www.bai.org/banking-strategies/articledetail/managing-customer-relationships-in-the-time-of-covid-19.

Melamedov, L., (2020). Coronavirus (COVID-19) and the banking industry: impact and solutions, Lightico, Retrieved from https://www.lightico.com/blog/coronaviruscovid-19-and-the-banking-industry-impact-and-solutions/.

Mora, A.G., (2020). Patterns-and some implications—of Covid-19 financial sector policy interventions, World Bank Blogs, Retrieved from https://blogs.worldbank.org/psd/patterns-and-some-implications-covid-19financial-sector-policy-interventions.

NBR - National Bank of Romania, (2020). Monetary indicators - April 2020, Retrieved from https://www.bnr.ro/page.aspx?prid=17837.

NBR - National Bank of Romania, (2019). Financial Stability Report, Retrieved from https://www.bnr.ro/DocumentInformation.aspx?idDocument=33672\&idInfoClass= 19968.

Pelau, C., Stănescu, M., Șerban, D., (2019). Big-Data and Consumer Profiles-The hidden traps of data collection on social media networks. Proceedings of the International Conference on Business Excellence, 13(1), 1070-1078.

Pop, N.A., (2020). Contemporary Directions in the Development of Romanian Academic Marketing in Favor of Increasing the Performance of the Organization. In: Fotea S., Fotea I., Văduva S. (eds) Challenges and Opportunities to Develop Organizations Through Creativity, Technology and Ethics. GSMAC 2019. Springer Proceedings in 
Business and Economics. Springer, Cham, 17-35, https://doi.org/10.1007/978-3030-43449-6_2.

PwC, 2020. How retail banks can keep the lights on during the COVID-19 crisis - and recalibrate for the future, Retrieved from https://www.pwc.com/us/en/library/covid-19/coronavirus-impacts-retailbanking.html.

Sako, M., (1992). Prices, Quality and Trust, Inter-Firm Relations in Britain \& Japan, Cambridge: Cambridge University Press.

S\&P Global Ratings, (2020). How COVID-19 Is Affecting Bank Ratings: May 2020 Update, Retrieved from https://www.spglobal.com/ratings/en/research/articles/200507how-covid-19-is-affecting-bank-ratings-may-2020-update-11480552.

Van Acker, V. (2016). Lifestyle and modal choices: Defining, measuring and using the 'lifestyle'concept. Transportation Research Record, 2495(1), 74-82. https://doi.org/10.3141/2495-08.

Vargas, V.M., (2019). The new economic good: Your own personal data. An integrative analysis of the Dark Web. Proceedings of the International Conference on Business Excellence, 13(1), 1216-1226. https://doi.org/10.2478/picbe-2019-0107.

Venkatesh, V., Davis, F.D., (2000). A theoretical extension of the technology acceptance model: Four longitudinal field studies. Management science, 46(2), 186-204. https://doi.org/10.1287/mnsc.46.2.186.11926.

Vessey, S., Ott, C., Dimidschstein, F., (2020). How banks can strategically respond to Covid19 challenges, Consultancy.eu, Retrieved from https://www.consultancy.eu/news/4096/how-banks-can-strategically-respond-tocovid-19-challenges.

Vrânceanu, D. M., Țuclea, C. E., Țigu, G., (2020). Price search behaviour in digital markets-A perspective from Romania. Management \& Marketing. Challenges for the Knowledge Society, 15(2), 219-235. https://doi.org/10.2478/mmcks-2020-0014.

Waite, K., Harrison, T., (2015). Online banking adoption: We should know better 20 years on. Journal of Financial Services Marketing, 20(4), 258-272. https://doi.org/10.1057/fsm.2015.19.

Wooldridge, J.M., (2009). Introductory Econometrics. A Modern Approach, 4th edition, Mason: South-Western Cengage Learning.

World Economic Forum, (2020). Impact of COVID-19 on the Global Financial System Platform for Shaping the Future of Financial and Monetary Systems.

Recommendations for Policy-Makers Based on Industry Practitioner Perspectives, Retrieved from

http://www3.weforum.org/docs/WEF_Impact_of_COVID_19_on_the_Global_Financia 1_System_2020.pdf.

Wu, M., Jayawardhena, C., Hamilton, R., (2014). A comprehensive examination of internet banking user behaviour: evidence from customers yet to adopt, currently using and stopped using. Journal of Marketing Management, 30(9-10), 1006-1038. https://doi.org/10.1080/0267257X.2014.935459.

Zhang, T., Lu, C., Kizildag, M., (2018). Banking "on-the-go": examining consumers' adoption of mobile banking services. International Journal of Quality and Service Sciences, 10(3), 279-295. https://doi.org/10.1108/IJQSS-07-2017-0067. 
Zolait, A.H.S., (2014). The nature and components of perceived behavioural control as an element of theory of planned behaviour. Behaviour \& Information Technology, 33(1), 65-85, https://doi.org/10.1080/0144929X.2011.630419. 